\title{
AVOIDING TENANCY LEGISLATION: SHAM AND CONTRACTING OUT REVISITED
}

\author{
SUSAN BRIGHT*
}

"This device ... is not permissible." 1

How can we know what is permissible and what is not when it comes to devices designed to avoid tenancy legislation? Devices pop up in different guises. In the agricultural tenancy field, a variety of methods have been used to try to avoid security of tenure by ensuring that the farmer tenant will not serve a counter-notice: some have proved effective, ${ }^{2}$ but on the whole, the courts have held them ineffective. ${ }^{3}$ In the residential context there is again mixed success: licences which are really disguised leases will not succeed, ${ }^{4}$ nor will agreements to give up possession, ${ }^{5}$ but letting to a company does work. $^{6}$ By contrast, devices used to avoid the enfranchisement laws have tended to meet with better success. ${ }^{7}$ Even unsuccessful devices are not attacked with the same weapon: courts have variously referred to sham, pretence, the artificial device doctrine developed in tax avoidance cases, statutory construction and unlawful contracting out. In consumer cases the unfair terms legislation can no doubt now be added to this armoury. ${ }^{8}$ Recently, in Bankway Properties v. Pensfold-Dunsford ${ }^{9}$ Arden L.J. conflated some of these approaches, striking down a provision which was "in substance an unlawful contracting out or evasion of an Act of Parliament". Pill L.J., the other member of the Court of Appeal in Bankway, had difficulties with this concept and rested his decision, also invalidating the "device", on "inconsistency with the statutory purpose" of the agreement.

* St Hilda's College, Oxford.

${ }^{1}$ Bankway Properties Ltd. v. Pensfold-Dunsford [2001] EWCA Civ. 528 at para. [56], per Arden L.J.; [2001] 1 W.L.R. 1369.

${ }^{2}$ See Barrett v. Morgan [2000] 2 A.C. 264.

${ }^{3}$ Johnson v. Moreton [1980] A.C. 37; Gisborne v. Burton [1989] Q.B. 390; Featherstone v. Staples [1986] 1 W.L.R. 861.

${ }^{4}$ Street v. Mountford [1985] A.C. 809; AG Securities v. Vaughan; Antoniades v. Villiers [1990] 1 A.C. 417.

${ }^{5}$ Barton v. Fincham [1921] 2 K.B. 291; Appleton v. Aspin [1988] 1 W.L.R. 410.

${ }^{6}$ Hilton v. Plustitle Ltd. [1989] 1 W.L.R. 149.

7 Jones v. Wrotham Park Settled Estates [1980] A.C. 74; Belvedere Court Management Ltd. v. Frogmore Developments Ltd. [1997] Q.B. 858.

8 The Unfair Terms in Consumer Contracts Regulations 1999, S.I. 1999/2083.

9 Bankway Properties Ltd. v. Pensfold-Dunsford [2001] EWCA Civ. 528; [2001] 1 W.L.R. 1369. 
There is no doubt that Bankway involved a device intended to avoid the security of tenure provisions in the Housing Act 1988. The property was let on an assured tenancy to tenants in receipt of housing benefit, at an initial rent of $£ 4,690$ per annum but with a review clause (clause 8(b)(iii)) which provided for the rent payable to be increased to $£ 25,000$ per annum, well above the market rent. ${ }^{10}$ Under the assured tenancy regime possession can only be obtained by court order if a ground for possession is proven, but the parties are free to agree both initial rents and provisions for rent review. It is clear that the landlord's aim in Bankway was that when the rent was put up to $£ 25,000$ the tenants would either chose to leave the property because of the unaffordable rent or would fall into arrears with the rent, thus generating a mandatory ground for possession. In the event, the tenants stayed and, predictably, fell into arrears with the rental payments leading the landlord to seek possession on the grounds of these rent arrears. As Arden L.J. observed, the landlord "never expected to receive rent of $£ 25,000$ per annum and intended that it should only invoke clause 8(b)(iii) as a means of recovering possession". ${ }^{11}$

By setting aside the possession order given at first instance, the Court of Appeal marked its disapproval of the blatant attempt to avoid the security of tenure regime that exists for assured tenancies. Disapproval must not, however, be allowed to cloud legal judgment and the question that will be explored here is whether the reasoning used by Arden and Pill LJ.J. involved application of established legal authority. The varied legal responses that there have been to devices to avoid tenancy legislation make for rather murky legal waters. The first part of this article, digressing from the Bankway decision itself, will seek to provide a chart for navigating these waters consistently with previous law. The second part of the article will then explore the decision in Bankway.

\section{Charting the Legal Waters}

Avoidance techniques generally fall into two broad categories. Although there is no clear, bright line between them, the first involves re-routing the legal relationship so as to take it outside the

${ }^{10}$ Although not proven in the case it appears that the reason why an assured tenancy was used, rather than the assured shorthold tenancy which would confer no security of tenure, was because the landlord was seeking to use tax breaks available under Business Expansion Schemes: see paras. [17]-[19], Bankway Properties Ltd. v. Pensfold-Dunsford [2001] EWCA Civ. 528; [2001] 1 W.L.R. 1369. By the Finance Act 1988 these tax concessions were available only for a five year period and many BES companies were planning to exit the rental market at the end of that period.

${ }^{11}$ Bankway Properties Ltd. v. Pensfold-Dunsford [2001] EWCA Civ. 528 at para. [54]; [2001] 1 W.L.R. 1369 
remit of the protective legislation and the second involves some provision within the tenancy agreement which seeks to avoid statutory control. Within the residential tenancy context, examples of re-routing include the use of a licence instead of a lease, and letting to a company instead of an individual: both of these methods (if successful) result in an occupation agreement which is not regulated. An example of the second method is a promise by a tenant to give up possession: the tenancy is protected under the legislation but there is a promise that security of tenure will not be claimed. The reason for noting this broad distinction is because different legal responses tend to be used within these categories.

Re-routing is effective as an avoidance technique, so long as it is genuine. What is meant by genuine will be explored in more detail later on. The effect of re-routing is to avoid triggering statutory control. Much of the housing legislation only bites on leases to individuals, and so it is open to an owner to take advantage of this either by licensing use of his property (rather than leasing) or by insisting on a letting to a company. In the agricultural sector it is possible to avoid security of tenure by letting under what is known as a Gladstone v. Bower ${ }^{12}$ letting, which is a fixed term letting between 12 and 24 months. In Belvedere v. Frogmore ${ }^{13}$ the landlord avoided triggering the right of first refusal on a sale of the reversion by granting intermediate leases. In these cases the reason why a transaction has been structured a particular way, even a highly artificial way, may be to avoid the statutory control but this does not, by itself, make it unlawful. So long as the legal route chosen is genuine, then it can be effective. In Jones v. Wrotham Park a scheme used to discourage enfranchisement claims being made had the effect of increasing by more than ten times the price that a tenant had to pay in order to enfranchise. The plan was described by Lord Salmon as ingenious, a device to discourage tenants from exercising their rights under the Leasehold Reform Act 1967, whereas Lord Russell condemned such descriptions as "irrelevantly pejorative: a man is entitled to avoid a claim against his prima facie legal rights by adoption of a genuine disposition of those rights". ${ }^{14}$ The case law responding to attempts to re-route the relationship has therefore concentrated on testing what is genuine:

${ }_{12}^{12}$ [1960] 1 Q.B. 170, confirmed by Court of Appeal [1960] 2 Q.B. 384.

13 Belvedere Court Management Ltd. v. Frogmore Developments Ltd. [1997] Q.B. 858.

14 Jones v. Wrotham Park Settled Estates [1980] A.C. 74, 113. Reviewing cases on sham, Staughton L.J. said in Welsh Development Agency v. Export Finance Co. Ltd. [1992] B.C.L.C. 148, 185: "The problem is not made any easier by the variety of language that has been used: substance, truth, reality, genuine are good words; disguise, cloak, mask, colourable device, label, form, artificial, sham, stratagem and pretence are 'bad names', to adopt the phrase quoted by Dixon J. in Palette Shoes Pty. Ltd. v. Krohn (1937) 58 C.L.R. 1 at 28." 
this it has done through the doctrines of sham, pretence, and labelling.

The second group is harder to describe. Although the legal relationship falls within a regulated category there is also some kind of agreement which will prevent the tenant from claiming rights that he would otherwise have. Most examples of this have occurred in the agricultural context but there are some residential examples, such as in Barton v. Fincham ${ }^{15}$ where, in return for a payment of $£ 20$, the tenant agreed to give vacant possession. In the agricultural cases governed by the Agricultural Holdings Acts 1948 and $1986^{16}$ the aim has been to prevent the protected tenant from serving a counter-notice in response to being served with a notice to quit-unless a counter-notice is served there is nothing to stop the landlord from recovering possession, but if a counter-notice is served he can only get possession with the consent of the Agricultural Lands Tribunal and this can only be given on specified grounds. Those cases in which the protected tenant has effectively agreed not to claim security ${ }^{17}$ have held the device non-effective, almost always on the grounds of statutory construction although public policy is sometimes additionally called into play. Where, however, through the agreement of persons other than the tenant, a situation is created which brings the tenancy to an end without the need to serve a notice to quit on the tenant, this has been effective. $^{18}$

Bankway certainly did not involve re-routing as the tenants clearly had an assured tenancy. Nor does it, however, come within the second group in the way that it has been described here, as the tenants were not being prevented from claiming rights that they would otherwise have: what the tenants agreed to was a rent increase, it is only in an indirect way that this erodes their security of tenure. Whether this is a material distinction we shall consider later.

\section{Step One: Ascertaining the Legal Nature of the Relationship}

Echoing the division of avoidance techniques into two broad categories, the legal response can be described as a two-stage

${ }^{15}$ [1921] 2 K.B. 291.

16 Similar schemes of protection applied under the 1948 and 1986 Acts but for new lettings entered into after the Agricultural Tenancies Act 1995 there is much less regulation.

17 Either through an agreement to give up possession, Barton v. Fincham [1921] 2 K.B. 291, Appleton v. Aspin [1988] 1 W.L.R. 410, or agreeing not to serve a counter-notice, Johnson v. Moreton [1980] A.C. 37, or agreeing not to serve a counter-notice without the consent of a company controlled by the landlord, Featherstone v. Staples [1986] 1 W.L.R. 861.

18 Barrett v. Morgan [2000] 2 A.C. 264. Gisborne v. Burton [1989] Q.B. 390 may appear not to fit this analysis, but it will be argued below that, if correct, this is a case of re-routing as the tenancy to the wife was not genuine. 
enquiry. The first task of the courts is to ascertain the legal nature of the relationship: this is to see which route the legal relationship is following. Essentially this is a search for the genuine-to see if the apparent route is the true route. Having determined the true nature of the relationship, the task of the courts is then to apply the legislation to that relationship, which will include a determination whether any "contracting out" by the tenant is lawful (step two).

In structuring the relationship to avoid the protective legislation, there may be no element of "deception" at all. As noted earlier, the parties are entirely free to organise their affairs in a way that avoids the remit of statutory control. If this is the case, then the courts can move quickly to the next stage to determine how the legislation applies to this transaction. So, for example, in Belvedere v. Frogmore ${ }^{19}$ the landlord sought to avoid the rights of first refusal given to tenants under the Landlord and Tenant Act 1987 by selling long leases of the tenanted flats to an associated company. The Court of Appeal did not countenance any argument that these leases should be treated as null just because they were an "artificial device intended to circumvent a result the Act would otherwise have brought about": they were genuine property transactions. ${ }^{20}$

Given that these cases are driven by avoidance there is, however, often a degree of subterfuge involved and the first task is to determine what the true transaction is between the parties. This may require the court to look behind the form to the "substance and reality" of the transaction. The "disguise" cases are addressed by three overlapping legal doctrines: sham, pretence, and "labelling". The first two, sham and pretence, fall within what Staughton L.J. referred to in Welsh Development Agency v. Export Finance as the "external route, which is to do with showing, by reference to matters external to the written agreement, that the written agreement does not reflect the true agreement of the parties". ${ }^{21}$ The latter doctrine is referred to as the "internal route": taking the written agreement between the parties does it amount to a transaction of the legal nature that the parties ascribe to it? ${ }^{22}$

${ }^{19}$ Belvedere Court Management Ltd. v. Frogmore Developments Ltd. [1997] Q.B. 858.

20 Per Sir Thomas Bingham M.R. at p. 876.

${ }^{21}$ Welsh Development Agency v. Export Finance Co. Ltd. [1992] B.C.L.C. 148, 186, drawing on the comments (inter alia) of Lord Hanworth M.R. in Re George Inglefield Ltd. [1933] 1 Ch. 1 at pp. 19,23 .

22 See also Re Curtain Dream plc [1990] B.C.L.C. 925, 935, per Knox J.: “... a cloak may be liable to be torn aside for one of two reasons. One may be that the documents are shams, in the sense that they are not genuine documents and they say things which the parties did not intend actually to govern their relationship. The other way is by analysing the effect of the totality of the transaction and seeing whether, on its true construction, the totality of the relationship between the parties was one which amounts to a creditor-debtor relationship or a vendor and purchaser and repurchase relationship." 
The external route in disguise cases: sham and pretence

The doctrines of sham and pretence can each be invoked in order to show that the outward agreement does not represent the true intentions of the parties. Sham is essentially about saying one thing and doing another. It occurs where the paperwork is a lie, intended to mislead a third party, and both parties know that the true position is otherwise. Over time, sham has become a narrow doctrine and the dicta of Diplock L.J. in the Snook case has been elevated to the status of a formal definition of sham:

... it is, I think, necessary to consider what, if any, legal concept is involved in the use of this popular and pejorative word. I apprehend that, if it has any meaning in law, it means acts done or documents executed by the parties to the "sham" which are intended by them to give to third parties or to the court the appearance of creating between the parties legal rights and obligations different from the actual legal rights and obligations (if any) which the parties intend to create. One thing I think, however, is clear in legal principle, morality and the authorities (see Yorkshire Railway Wagon Co. v. Maclure ((1882) 21 Ch. D. 309); Stoneleigh Finance, Ltd. v. Phillips ([1965] 1 All E.R. 513, [1965] 2 Q.B. 537)), that for acts or documents to be a "sham", with whatever legal consequences follow from this, all the parties thereto must have a common intention that the acts or documents are not to create the legal rights and obligations which they give the appearance of creating. ${ }^{23}$

There are surprisingly few cases upon sham, and virtually none in the field of real property. Bhopal v. Walia provides a rare example. ${ }^{24}$ After the tenant moved into occupation at a monthly rent of $£ 300$, he signed a written tenancy agreement at the landlord's request which showed the rent as being $£ 450$ monthly in order to mislead the bank about the level of income that the property was producing. This was held by the Court of Appeal to be a sham.

Notwithstanding the great hesitancy with which Diplock L.J. began his description of sham ("what, if any, legal concept is involved"), it has become the standard definition. A sham is intended to mislead a third party or court about the true position. In Bhopal it was a bank that was misled. In a recent Court of Appeal case, Hitch v. Stone, it was the Revenue. ${ }^{25}$ The intention must be a common intention. ${ }^{26}$ The doctrine tends to look at whole

23 Snook v. London \& West Riding Investments Ltd. [1967] 2 Q.B. 786, 802.

2432 H.L.R. 302. See also Duarte v. Mount Cook Land Ltd. Q.B.D. 26.7.01, Crowley Q.C., in which documents presented as contracts for the sale of a lease were held to be shams.

25 Hitch v. Stone [2001] E.W.C.A. 63; [2000] S.T.C. 214.

${ }^{26}$ Hitch v. Stone [2001] E.W.C.A. 63 at para. [69]; [2000] S.T.C. 214. 
transactions as shams; but it is possible, though unusual, to have a sham in part so long as that part forms a discrete transaction within the whole. ${ }^{27}$ In order to prove a sham external evidence can be used: 'this will include the parties' explanations and circumstantial evidence, such as evidence of the subsequent conduct of the parties". ${ }^{28}$ The fact that a transaction has been entered into for avoidance purposes is not, however, relevant to whether it is a sham: "mere impropriety of motive is no ground for treating a transaction as a sham". ${ }^{29}$

In practice, the need for a common intention and for a whole transaction to be a sham limits the usefulness of the doctrine. There could not, for example, have been a sham in this strict sense in Antoniades v. Villiers where a couple were asked to sign separate licence agreements containing a provision, clause 16, which stated that the "licensor shall be entitled at any time to use the rooms together with the licensee and permit other persons to use all of the rooms together with the licensee ..." Given the size and layout of the accommodation, and the relationship between the couple, it was obvious that the "licensor" would not exercise this right. In holding the couple to have a tenancy and not separate licences, the House of Lords used a variety of language to explain why clause 16 should not be given its face value. Only Lord Oliver spoke of sham. ${ }^{30}$ Lord Jauncy described the licences as "dressing up", and Lords Bridge and Templeman spoke of "pretence". ${ }^{31}$ Indeed, in the House of Lords no reference was made to the Snook definition of sham.

In moving away from the language of sham to pretence there is the chance to introduce greater flexibility. Essentially, pretence will be found where there is no genuine intention to implement the agreement as it stands. This can also be said of sham, but there are not the same constraints about the need for a common intention and for the whole document to be a lie. Lord Donaldson M.R. clearly saw the two concepts operating differently in Aslan:

“... parties may succumb to the temptation to agree to pretend to have particular rights and duties which are not in fact any part of the true bargain ... [The] courts would be

${ }^{27}$ Hitch v. Stone [2001] E.W.C.A. 63 at para. [85]; [2000] S.T.C. 214

${ }^{28}$ Hitch v. Stone [2000] E.W.C.A. 63 at para. [65]; [2000] S.T.C. 214.

29 Per Knox J. in Chase Manhattan Equities Ltd. v. Godman [1991] B.C.L.C. 897, 921. See also Megarry J. in Miles v. Bull [1969] 1 Q.B. 258, 264; Neuberger J. in National Westminster Bank plc v. Jones [2001] 1 B.C.L.C. 98 at para. [37].

30 "... they were sham documents designed to conceal the true nature of the transaction", $A G$ Securities v. Vaughan, Antoniades v. Villiers [1990] 1 A.C. 417, 470.

31 AG Securities v. Vaughan, Antoniades v. Villiers [1990] 1 A.C. 417, 462, per Lord Templeman: "It would have been more accurate and less liable to give rise to misunderstandings if I had substituted the word 'pretence' for the references to 'sham devices' and 'artificial transactions' [in Street v. Mountford [1985] A.C. 809 at p. 825]." 
acting unrealistically if they did not keep a weather eye open for pretences, taking due account of how the parties have acted in performance of their apparent bargain. This identification and exposure of such pretences does not necessarily lead to the conclusion that their agreement is a sham, but only to the conclusion that the terms of the true bargain are not wholly the same as that of the bargain appearing on the face of the agreement." 32

Throughout the speeches in Antoniades it is clear that the reason why the licences were found to be non-genuine was because there was never any intention to rely on clause 16 . Had they been applying the Snook concept of sham the House of Lords would have had to find a mutuality of intention to mislead, but there is no discussion in the speeches of whether both parties intended for clause 16 not to operate, nor was there a third party that they intended to mislead. Nor did it matter that the focus was on two aspects of the transaction rather than the transaction as a whole. ${ }^{33}$ The essence of pretence is that the agreement is a smokescreen. It is not sufficient to strike down a device on these grounds that it was intended or designed for the sole purpose of avoiding protective legislation, even if there is no other purpose served by it. As with sham, motive is irrelevant. It does not matter that the only reason why a particular route, however tortuous, is selected is to avoid statutory provisions: the test is simply one of whether or not the device is seriously intended. The transaction must be taken at face value unless it is shown that it was not genuine in the sense that the parties never intend to rely on that device.

Understanding the role of genuineness is the key to unlocking the apparent difficulties raised by the company let cases, and of explaining the decision in Gisborne v. Burton. ${ }^{34}$ By letting to a company, rather than an individual, a landlord is able to avoid the protective remit of housing legislation. In some instances, a landlord has therefore insisted on the letting being to a company even though the company is created solely to act as a tenant and is little more than a shell. Although it has been argued that the doctrine of pretence could be extended to company lets where the use of the company serves no independent commercial purpose and has been used solely as a device to avoid the protective remit of

32 Aslan v. Murphy; Duke v. Wynne [1990] 1 W.L.R. 766, 770-771.

33 Clause 16, and the use of two separate agreements. Similarly, in Aslan v. Murphy; Duke v. Wynne [1990] 1 W.L.R. 766, 772-773, Lord Donaldson M.R. saw sham as operating on the whole, whereas pretence can operate on part- "What [the judge] should have done ... was to consider whether the whole agreement was a sham and, if it was not, whether in the light of the factual situation the provisions for sharing the room and those depriving Mr. Murphy of the right to occupy it for 90 minutes out of each 24 hours were part of the true bargain between the parties or were pretences."

34 [1989] Q.B. 390. 
statute, ${ }^{35}$ this extension has been firmly rejected by the courts. ${ }^{36}$ If the letting is genuinely to a company the fact that the company is used solely to avoid the occupier having protected status is irrelevant: the test is whether the legal reality is that the property has been let to a company. ${ }^{37}$

Gisborne v. Burton is a more difficult case. In order to avoid security of tenure, a landowner granted an agricultural tenancy to his wife, who in turn sublet the farm. On termination of the headtenancy (which the wife would not oppose), the sub-tenancy would automatically come to an end. By using the device of the intermediate letting to the wife, the farmer was denied security of tenure. The majority of the Court of Appeal held that this was ineffective and the reality was that there was a letting to the farmer. Dillon L.J. drew heavily upon the "Ramsay principle" in taxation cases, taking the view that by two preordained steps an agricultural tenancy was granted to the farmer. ${ }^{38}$ Russell L.J. played down the significance of the principles developed in tax avoidance cases; preferring to rely on "the true intention of the parties" he took the view that the farmer was not a "genuine" subtenant but remained "in reality" a tenant. The Gisborne case can therefore be explained, in accordance with the argument being put in this article, on the basis that the letting to the wife was "not genuine" as there was never any intention that the wife should farm the land. Therefore the "pretender" could not rely on that letting to deny security of tenure to the farmer. Indeed, in Hilton v. Plustitle, Croom-Johnson L.J. explains Gisborne as a case where "the documents were never intended to be acted upon". 39 Nonetheless, although Gisborne can be said to fit this theory, it is an uncomfortable fit. This article argues that in order to determine the legal nature of a transaction it is possible to overlook only the non-genuine - genuine, but avoidance motivated, provisions must be given effect to. It is possible to argue, consistently with the majority

35 Bright, "Beyond Sham and Into Pretence" (1991) 11 O.J.L.S. 136.

${ }^{36}$ Hilton v. Plustitle Ltd. [1989] 1 W.L.R. 149; Kaye v. Massbetter [1991] 2 E.G.L.R. 97.

${ }^{37}$ Hilton v. Plustitle Ltd. [1989] 1 W.L.R. 149, 155, per Croom-Johnson L.J.: "[The company] was the only tenant to whom [the landlord] was prepared to let the property, and the covenants in the lease were perfectly capable of being complied with by the company through its nominee ... and enforced against the company ... [The] transaction did represent the true position."

38 The "Ramsay" principle itself is still evolving with recent cases displaying a less interventionist approach: see, especially, Macniven v. Westmoreland Investments Ltd. [2001] UKHL 6; [2001] 2 W.L.R. 377. There is also considerable doubt about whether the same approach applies to real property cases: "I am not for my part satisfied that in the field of real property the principles in WT Ramsay Ltd. v. IRC [1982] A.C. 300 and Furniss v. Dawson [1984] A.C. 474 entitle the court simply to ignore or override apparently effective transactions which on their face confer an interest in land on the transferee." Belvedere Court Management Ltd. v. Frogmore Development Ltd. [1997] Q.B. 858, 876, per Sir Thomas Bingham M.R.

${ }^{39}$ Hilton v. Plustitle Ltd. [1989] 1 W.L.R. 149, 155. 
in Gisborne, that the letting to the wife was simply non-genuine. However, the thrust of the majority arguments was that the courts would overlook the intermediate tenancy where it was simply an artificial device the only object of which was to disguise the grant of a tenancy. The primary focus was not upon the question whether or not it was a genuine letting. The powerful dissent of Ralph Gibson L.J. provides a closer fit. The reality was that the "parties did not intend that [the farmer] should be the direct tenant of [the landowner] but they all intended that he should not be". ${ }^{40}$ As he stated earlier in his judgment, "the courts have never claimed the power to treat a transaction in private law between private individuals as something other than it really is merely because the social purpose of some legislation would be served by so treating it', 41

It is reasonably clear from what Lord Templeman said in Antoniades that a move to the language of pretence was intended to loosen the shackles of sham. In practice, however, the courts have not readily adopted the language of pretence and, particularly in non-tenancy cases, the dead hand of Snook lives on. It is timely therefore to question what it is that Snook really stands for. As discussed earlier, the conditions for Snook are fairly tightly defined, in particular with the requirement that there be a common intention to deceive. A closer examination of the case law does, however, support a different reading of Snook and sham.

In Snook itself it is true that the majority of the Court of Appeal found that the transactions there involved were not "sham" because one of the parties was "innocent" of the sham. The case involved tri-partite dealings relating to financing raised on the security of a car. From the Court of Appeal ruling and what Diplock L.J. said in the passage quoted earlier it does seem that there must be a common intention in order for there to be a sham. But we do need to look at this a little more closely. Diplock L.J.'s remarks were somewhat hedged: there is some hesitancy about sham itself ("what, if any, legal concept is involved ...", and "if it has any meaning in law"), and the effect of a finding of sham is not touched upon ("with whatever legal consequences follow from this"). Admittedly, he expresses clarity about one thing: the need for a common intention. But this, too, needs examining in context. In the particular case the fact that one of the parties was "innocent" of the sham meant that the transaction could not be avoided as against them, with the end result that title to the car had passed to them and they were not liable in conversion for 
having repossessed the car. One explanation is, indeed, that there was no sham because there was no common intention. Diplock L.J. referred to two cases as authority for the "common intention" rule. In both of these cases ${ }^{42}$ the Court of Appeal had similarly declined to set aside transactions as sham where one of the parties to the transaction was ignorant of the deceit, Jessel M.R.'s remarks in Yorkshire Railway Wagon Co. v. Maclure laying the foundation of the common intention rule: "But even if the Wagon Company understood it as a loan, in order to set aside the deed, that is to treat it as a nullity, you must shew that the Railway Company were parties to the understanding. You cannot have a bargain on one side, and if the Railway Company only sealed this document because it carried out their intention, you cannot say it is not the real contract between the parties."43

As Diplock L.J. says, a transaction will not be void as a sham if the sham is not known to both parties. But it does not follow from this that no account is taken of the sham if it is intended by only one of the parties. Diplock L.J. draws on legal principle, morality and authority as supporting the common intention rule, but they also support the view that a "unilateral" sham can have some effect too. Another way of looking at Snook and Yorkshire Railway Wagon is to say that the party intending the documents to deceive cannot denounce the transaction as a sham as against a party who is ignorant of the sham. ${ }^{44}$ If only one of the parties has an intention to deceive, although the transaction as a whole will not be void, that party may be prevented from relying on, or denying (depending on the context), the shamful intent. In Midland Bank v. Wyatt $^{45}$ a husband and wife jointly owned a home and, in order to protect his family from financial risk, the husband entered a trust deed declaring that his interest in the home was held for his wife and children. This declaration of trust was never acted upon but was "put in the safe for a rainy day". His wife had signed the deed but was found not to have been aware of its import. When the bank obtained a charging order, the husband resisted it, pointing to the trust deed as showing that he retained no beneficial interest in the home. Mr. Dem Young Q.C. held that the deed was a sham even though the wife had not understood what she was

\footnotetext{
42 Yorkshire Railway Wagon Co. v. Maclure (1881) 21 Ch. 309; Stoneleigh Finance Ltd. v. Phillips [1965] 1 All E.R. 513.

43 (1881) 21 Ch. 309, 314.

${ }^{44}$ This accords with the objective intention of contract law, but there is a difference. In sham, it will be argued, the shammer cannot rely on the formal, objective, document as a defence if he subjectively intended something else and the objective document would prevent the party ignorant of the sham relying on a statutory code of protection.

45 Midland Bank v. Wyatt [1995] 1 F.L.R. 696.
} 
signing. ${ }^{46}$ There is also some, albeit rather slim, support for a trust being held to be a sham where the settlor retained effective control over the trust assets, the trustee being a mere agent or nominee. ${ }^{47}$ In this situation it would make no sense to require mutuality as a trust is an essentially unilateral act.

\section{Sham and pretence re-interpreted}

Much of value was lost when the dicta of Diplock L.J. in Snook became hardened law and it is clear that in $A G$ Securities the House of Lords, and Lord Templeman in particular, was seeking to break away from these confines. Both sham and pretence are to do with the same thing, that is, to enable the true nature of a transaction to be revealed. The case law, although rather thin on this, does support a more sophisticated account of sham than is usually given and which accords better with "legal principle and morality". Whatever it is called, this refined doctrine of sham would be able to subsume within it the doctrine of pretence.

Where it is found that documents entered into give the appearance of creating legal rights and obligations between the parties that are not genuine, in the sense that there is no intention of honouring these obligations or enjoying the rights, ${ }^{48}$ then:

(i) where there is a common intention to deceive, that document will be void as between those parties. ${ }^{49}$ It is this automatic consequence of voidness, and possible impact upon third parties, that accounts for the reluctance of courts to find a sham and the need for very clear evidence that the

\footnotetext{
${ }^{46}$ This case could be viewed two ways. The judge said that the wife neither knew nor cared about what she was signing; in this sense it could be said that not knowing or caring counts as shamful intent, and that there was common intention, "Such a person would still be a party to the sham ..." (at 699). Elsewhere he seems to be saying that even if only one of the parties has a shamful intent, that party may be prevented from relying on his wrong: "Diplock L.J.'s observations in their proper context state no more than where a 'sham' transaction affects the rights of a third party the 'shammer' cannot rely on the sham transaction unless the third party is also a party to the sham. The 'shammer' is otherwise estopped by his conduct from so relying on the sham transaction. ... I do not understand Diplock L.J.'s observations regarding the requirement that all the parties to the sham must have a common interest to be a necessary requirement in respect of all sham transactions." (at p. 699)

47 Abdel Rahman v. Chase Bank (CI) Trust Company Ltd. [1991] J.L.R. 103, 147: “... the settlement was a sham on the facts, in the sense that it was made to appear to be a genuine gift when it was not", per Tomes, Deputy Bailiff for the Royal Court of Jersey.

48 See National Westminster Bank plc v. Jones [2001] 1 B.C.L.C. 98 at para. [45], per Neuberger J. In Miles v. Bull [1969] 1 Q.B. 258, 264 Megarry J. said that to show sham "it must be shown that the outward and visible form does not coincide with the inward and substantial truth." A sham document will usually be hiding a true agreement between the parties but it is not necessary to prove that there was an alternative "real" agreement: Chase Manhattan Equities Ltd. v. Goodman [1991] B.C.L.C. 897, 922, Knox J.

49 See, for example, Bhopal v. Walia 32 H.L.R. 302 where the tenant was able to prove that the true rent was $£ 300$ rather than the $£ 450$ presented in the sham tenancy agreement.
} 
provisions are not genuine. ${ }^{50}$ If an innocent third party has relied upon the form of the document, the parties may be estopped from setting up the invalidity of the document. ${ }^{51}$

(ii) where only one of the parties intended to deceive or inserted provisions which he had no intention of honouring and the other party was ignorant of this (or did not "know or care" $" 52$ ) or simply went along with it through absence of choice, ${ }^{53}$ the party with the deceitful (non-genuine) intent:

(a) will not be allowed to take advantage of the formal appearance of rights to the disadvantage of an "innocent" party. This means that a person innocent of the sham will be allowed to rely upon external evidence to prove that the formal agreement is a sham/non-genuine. ${ }^{54}$ Similarly, when applied to the residential tenancy cases, the occupier is allowed to prove that the "licensor" never had any intention of relying upon clauses which prevent a tenancy arising, as, for example, with the "sharing clause" in $A G$ Securities or the clause requiring a daily 90 minute departure in Aslan. As Lord Donaldson M.R. said in Aslan, it "is the true rather than the apparent bargain which determines the question: tenant or lodger?"

(b) will not be allowed to set aside the formal document by proving it is a sham and thereby rely on the real/true agreement if an innocent person has relied upon the formal agreement. The Yorkshire Railway case and Snook are examples of this: in both cases the court held that there was no sham because there was no common intention to deceive but the effect was the same as saying that the

${ }^{50}$ Compare National Westminster Bank plc v. Jones [2001] 1 B.C.L.C. 98, Neuberger J. especially at para. [59] and para. [68]. Throughout his judgment it is clear that a claim that a transaction is not genuine will be hard to prove.

${ }^{51}$ See National Westminster Bank plc v. Jones, [2001] 1 B.C.L.C. 98 at para. [60], per Neuberger J.: "If a tenancy agreement is a sham, and an innocent third party accepts it as security for a loan to the tenant, then it seems to me that the third party is entitled to treat the tenancy in existence as against the landlord and as against the tenant: it can scarcely lie in the mouth of either of them to contend that the tenancy agreement does not exist as against the mortgagee in such circumstances." By contrast, in Bhopal v. Walia (1999) 32 H.L.R. 302 the tenant was not estopped from proving the sham as against the purchaser of the reversionary interest as the purchaser had not relied in any way upon the terms of the sham agreement.

52 Midland Bank v. Wyatt [1995] 1 F.L.R. 696.

53 As in AG Securities v. Vaughan, Antoniades v. Villiers [1990] 1 A.C. 417.

${ }^{54}$ For example, Midland Bank v. Wyatt [1995] 1 F.L.R. 696. In Eaton Square Properties Ltd. v. Eamon Oliver Plunkett Laserian O'Higgens (CA, 20.10.2000) counsel had argued an analogy with the cases on illegality and trusts whereby a court cannot hear a party argue his own iniquity as a reason why a particular document cannot take the effect that it appears to have. The Tinsley v. Milligan line of cases do appear to involve similar principles in that the case is usually that the apparent transfer of ownership is a pretence in order to disguise or hide the true ownership from a third party, although in these cases the "shammer" may be allowed to prove it was a sham. 
"shammer" could not set aside the sham document to the detriment of the innocent party.

\section{The internal route: labelling the transaction}

Whereas sham and pretence are to do with revealing the true agreement between the parties, labelling is to do with deciding the correct legal classification of that agreement. In order to find the legal nature of the relationship, both steps may be necessary as, for example, in $A G$ Securities where it was first necessary for the House of Lords to discern the true rights between the parties and then to determine whether the label of "licence" that had been put upon the agreement was correct. On the whole, the parties are not at liberty to choose which label attaches to their relationship, at least in the context of an unequal bargaining relationship. ${ }^{55}$ As Lord Templeman famously remarked in Street v. Mountford, the manufacture of a five pronged implement for manual digging creates a fork even if the manufacturer insists upon calling it a spade. ${ }^{56}$ This approach is not unique to tenancy law. It can be seen, for example, in employment law where, similarly, classification of the relationship is crucial in determining whether the "worker" gains extensive rights under the employment protection legislation. Here, too, the courts have not treated the designation by the parties of the relationship as either one of "employment" or of "services" as determinative but as a matter of substance for the court. ${ }^{57}$

Street itself was a straightforward labelling case: it was conceded that Mrs. Mountford enjoyed exclusive possession and the question came down to one of whether the parties were free to call this agreement a licence, or not. The House of Lords said not: the grant of exclusive possession meant that a lease had been created. Not all cases are this straightforward. Although the internal route looks only to the actual agreement reached, this agreement may contain inconsistencies. As Staughton L.J. observed in the Welsh Development Agency case (in the context of deciding whether a commercial document effected a charge or a sale), "the correct process, when one is following the internal route, is to look at the

${ }^{55}$ Hill explores this issue in the context of proprietary rights: Intention and the creation of proprietary rights: are leases different? (1996) 16 L.S. 200. He argues that the general rule is that where an interest displays the substantive characteristics of a proprietary right, the parties can nonetheless choose to characterise the interest as personal. The lease/licence distinction is treated differently because of inequality of bargaining power.

56 Street v. Mountford [1985] A.C. 809 at 819. See also Aslan v. Murphy; Duke v. Wynne [1990] 1 W.L.R. 766, 770, per Lord Donaldson M.R., "The labels which parties agree to attach to themselves or to their agreements are never conclusive and in this particular field, in which there is enormous pressure on the homeless to agree to any label which will facilitate the obtaining of accommodation, they give no guidance at all."

57 McMeechan v. Secretary of State for Employment [1997] I.C.R. 549. 
operative parts of the document, in order to discover what legal transaction they provide for. If some parts appear to be inconsistent with others in this respect, a decision must be made between the two. This is what I understand by ascertaining the substance of the transaction." 58

\section{Bankway and step one}

In Bankway the legal route being followed was clear. The tenants had an assured tenancy and there was no attempt to disguise this. If anything could be described as a disguise in Bankway it was the provision for rent of $£ 25,000$ per annum. Because there was never any expectation that this rent would be paid, Arden L.J. viewed the clause as a disguise - it "masqueraded as a provision for an increase of rent: it was not in substance a provision for the payment of rent. It was introduced to enable the landlord to bring the assured tenancy to an end when it chose." [para. 54]. Even though there was no realistic expectation of payment, this does not, however, mean that it was not a genuine provision for rent. When previous cases have referred to the "substance and reality" of a transaction, they have been searching to find whether there was any serious intention of implementing and honouring the clauses. In Bankway the review clause was not "dressing up"; it was a genuine clause which the landlord intended to rely upon.

\section{Step Two: Applying the Statute to the Transaction}

Once the true legal route followed has been mapped, the courts then have the task of applying the relevant legislation to it. ${ }^{59}$ In some cases application of the legislation to the transaction is straightforward. It becomes more difficult, however, where there is a regulated relationship accompanied by an agreement which has the effect of denying statutory rights. For convenience, this will be called "contracting out" although, as will be seen, it is not entirely clear exactly what contracting out is.

Some statutes contain specific provisions against contracting out. Under the Agricultural Holdings Act 1986, for example, a tenancy for more than two years will continue as a yearly tenancy at the

58 Welsh Development Agency v. Export Finance Co Ltd. [1992] B.C.L.C. 148. See also, Mustill L.J. in Hadjiloucas v. Crean [1988] 1 W.L.R. 1006 at p. 1019: "the document does precisely reflect the agreement between the parties, but where the language of the document (and in particular its title or description) superficially indicates that it falls into one legal category, whereas when properly analysed in the light of surrounding circumstances it can be seen to fall into another".

59 This echoes the steps proposed by Lord Hoffmann in response to tax avoidance schemes in Macniven v. Westmoreland [2001] UKHL 6; [2001] 2 W.L.R. 377. See also Buckley L.J. in Shell-Mex \& BP Ltd. v. Manchester Garages [1971] 1 All E.R. 841, 846: "One has first to find out what is the true nature of the transaction and then see how the Act operates on that state of affairs, if it bites at all." 
end of the two years unless ended by notice (s. 3) and section 5 states that this is to apply "notwithstanding any agreement to the contrary". Other statutes contain general anti-avoidance provisions which are meant to catch not only the more blatant and direct attempts to contract out, but the subtle and indirect. So, for example, any agreement is void which has the effect of excluding, modifying or otherwise frustrating the impact of the Landlord and Tenant (Covenants) Act 1995. ${ }^{60}$ The hardest cases are those, however, where the statute is silent on the particular form chosen. In this situation, it would seem to follow that if the contracting out provision is not prohibited it should succeed. For the courts to strike down as unlawful what has not been prohibited by statute would seem a usurpation of the role of the legislature.

At first blush, a case that comes close to doing this, at the highest judicial level, is Johnson v. Moreton. ${ }^{61}$ An agricultural tenant covenanted not to serve a counter-notice upon the landlord if served with a notice to quit. Under the relevant legislation, the Agricultural Holdings Act 1948, the farmer tenant has security by being able to contest a notice to quit served by the landlord. $\mathrm{He}$ does this by serving a counter-notice under section 24, and the notice to quit cannot then have effect unless the landlord applies for, and obtains, the consent of the Agricultural Land Tribunal to its operation. In Johnson, the tenant was served with a notice to quit and in breach of the agreement in the lease he served a counter-notice. The landlords treated this counter-notice as valid but then served a second notice to quit stating that the landlords' interest in the farm had been materially prejudiced by the tenant's breach in serving the counter-notice: if this second notice to quit was effective it would entitle the landlords to take possession without going through the Agricultural Land Tribunal. Some sections of the 1948 Act expressly excluded contracting out, by using phrases such as "this section shall have effect notwithstanding any agreement to the contrary"; other sections expressly permitted contracting out. But section 24 was silent. The House of Lords was unanimous in holding that the covenant "not in any event to serve a counter-notice" was invalid.

Although the decision in Johnson was unanimous, four Law Lords gave speeches and there are different strands of reasoning that can be seen. Lords Salmon and Hailsham relied heavily on the particular wording used in section 24 of the Act; although wider themes can be seen in their judgments they were careful to decide

${ }^{60}$ Section 25. In a similar vein, see Landlord and Tenant Act 1954, s. 38(10), and in an employment context, Employment Rights Act 1996, s. 203.

${ }^{61}$ [1980] A.C. 37. 
the case as a matter of statutory construction. Lord Russell considered that it could not have been the intention of Parliament that tenant farmers should be able to bargain away the security conferred on them by the statute. Undoubtedly this was a wider line of reasoning, but it is nonetheless difficult to know whether he intended to promote a principle of more general application beyond the agricultural context. ${ }^{62}$ It is in Lord Simon's speech (with whom Lord Edmund-Davies expressed especial agreement) that the most general principle emerges:

Where it appears that the mischief which Parliament is seeking to remedy is that a situation exists in which the relations of parties cannot properly be left to contractual regulation, and Parliament therefore provides for statutory regulation, a party cannot contract out of such statutory regulation (albeit exclusively in his own favour), because so to permit would be to reinstate the mischief which the statute was designed to remedy and to render the statutory provision a dead letter. ${ }^{63}$

The divergence in judicial reasoning makes it difficult to determine what principle emerges from Johnson. All of the speeches place importance on the public interest involved in farming. Although Lord Hailsham refers to a public interest in protecting vulnerable members of society, and refers to the rent legislation as an example, his decision ultimately is based upon the wording of the statute. It is really only in Lord Simon's speech that a principle of application beyond the agricultural tenancies context is seen. It must also be noted that Johnson is a case where the protected party himself was involved in the agreement that potentially deprived him of statutory protection - the case is not authority for public policy striking down agreements between other parties which will have the effect of preventing the protected party from claiming statutory rights. $^{64}$

There are no other cases to help guide us on the width of Johnson. Other contracting out cases have been decided either on the basis of statutory wording, or as involving the same principle as Johnson. In Barton v. Fincham ${ }^{65}$ the tenant had promised to serve a notice to quit and to give up possession in return for $£ 20$ but, having served the notice to quit, then refused to leave. Declining to order possession, the Court of Appeal relied upon the wording of the statute which conferred jurisdiction to order possession only on

\footnotetext{
${ }^{62}$ Later cases in which specific speeches in Johnson v. Moreton [1980] A.C. 37 have been drawn on have been in the agricultural tenancy context and have referred to Lords Salmon, Hailsham and Russell (Gisborne v. Burton [1989] Q.B. 390 and Featherstone v. Staples [1986] 1 W.L.R. 861).

${ }^{63}$ [1980] A.C. 37,69

64 Barrett v. Morgan [2000] 2 A.C. 264

${ }^{65}$ [1921] 2 K.B. 291.
} 
specified grounds, which did not exist here. ${ }^{66}$ In Featherstone v. Staples ${ }^{67}$ land was farmed on a lease entered into with two brothers and a company controlled by the landlord. There was a provision that no counter-notice could be served without the consent of that company - in effect, the landlord, via the company, hoped to prevent the brothers from claiming security. The Court of Appeal upheld the validity of the counter-notice that was served by the brothers. Slade L.J. saw this as a case following inevitably from the decision in Johnson. ${ }^{68}$

\section{Bankway and step two}

It is only Lord Simon's opinion in Johnson that has potential application to Bankway, in saying that a party protected by statute cannot contract out of that protection. This raises the question of what "contracting out" is. In Johnson the tenant was not able to bargain away his right to serve a counter-notice; but the tenants in Bankway were not bargaining away rights. What the bargain did in Bankway was to create a situation that would, in all probability, cause a specified ground of possession to exist (the rent arrears). Is this contracting out?

\section{The REASONING IN BANKWAY}

This part of the article will consider the reasons given in Bankway that were to do with the "avoidance" aspects of the scheme. ${ }^{69}$

Having rejected the view that clause 8(b)(iii) was a sham, Arden L.J. accepts that there can be a variation of sham "where a question arises whether an agreement is not intended to have the effect stated but is intended to evade the operation of a statute out of which the parties cannot contract", ${ }^{70}$ leading ultimately to the crucial question which is whether clause 8(b)(iii) is an attempt in substance to evade a mandatory and comprehensive scheme. This doctrine she sees at work in a long line of cases. Overall, it is a somewhat peculiar list to extract such a wide principle from. Only

${ }_{67}^{66}$ A similar case based on more recent legislation is Appleton v. Aspin [1988] 1 W.L.R. 410.

${ }^{67}$ [1986] 1 W.L.R. 861.

68 "It must ... inevitably follow ... that, if A were to grant a tenancy of a holding to A, B and $\mathrm{C}$ and the tenancy agreement were to contain a condition by which $\mathrm{A}, \mathrm{B}$ and $\mathrm{C}$ as tenants agreed with A as landlord never to serve a counter-notice without A's consent, that condition would be no less void ..." (at 476). It made no difference that the condition was contained in a separate partnership agreement.

69 The Court of Appeal rejected arguments that the term had not been properly incorporated. In the future, the Unfair Terms in Consumer Contracts Regulations 1999, S.I. 1999/2083, might well strike down such provisions, but they were not in force when the tenancy agreement in Bankway was entered into. For discussion of the Regulations, see, Bright, "Winning the Battle against Unfair Contract Terms" (2000) 20 L.S. 331.

70 At paras. [42]-[43]. According to Arden L.J., it could not be a sham because there was not a "common subjective intention". Although this article argues that there can be a unilateral sham, there was no sham in Bankway because it was a genuine rent provision. 
the tenancy cases involve contracting out; ${ }^{71}$ the other cases are either to do with identifying the true nature of the legal relationship or with other areas of law altogether. In re Watson was to do with the correct classification of an agreement which was presented as a hire and purchase agreement but in reality was a licence to take personal chattels as security for a loan. ${ }^{72}$ Similarly, in Campbell Discount the House of Lords held that, notwithstanding the wording of a contractual damages clause, the reality was that it was a penalty provision: "It is well settled that when a court of law finds that the words which the parties have used in a written agreement are not genuine, and are not designed to express the real nature of the transaction but for some ulterior purpose to disguise it, the court will go behind the sham front and get at the reality. That, indeed, is what the court is doing when it declares that what is expressed as an agreement about liquidated damages is not a genuine agreement but cloaks the imposition of a penalty."73 The remaining cases have little to do with how sham is defined: one involved whether the Statute of Frauds prevented the Duchess from proving that the Duke of Marlborough had intended to reconvey a property to her, ${ }^{74}$ and the other related to whether there had been an unlawful sale at an undervalue according to the Companies Acts. ${ }^{75}$

At the heart of the test that Arden L.J. uses is the question whether there is "in substance an unlawful contracting out". ${ }^{76}$ Answering this involves establishing that the Housing Act 1988 provides a statutory scheme for security of tenure so that to provide an additional way of ending the tenancy would be an improper attempt to evade the Act [para. 49]; and that clause 8(b)(iii) is not in substance and reality a provision for the fixing of rent, but a provision to enable the landlord to recover possession otherwise than in accordance with the mandatory scheme [para. 51]. This is quite different from the approach that has been used in the previous case-law. "Substance and reality" has been used in earlier

${ }^{71}$ The tenancy cases she refers to have been discussed previously: AG Securities v. Vaughan, Johnson v. Moreton, and Gisborne v. Burton. Of these, only Johnson v. Moreton is obviously a contracting out case.

72 In re Watson; Ex p Official Receiver in Bankruptcy (1890) 25 Q.B.D. 27, 37, per Lord Esher M.R.: "I do not deny that people may evade an Act of Parliament if they can, but, if they attempt to do so by putting forward documents which affect to be one thing when they really mean something different, and which are not true descriptions of what the parties to them are really doing, the Court will go through the documents in order to arrive at the truth."

73 Campbell Discount Co. Ltd. v. Bridge [1962] A.C. 600, 634, per Lord Devlin.

${ }^{74}$ In re Duke of Marlborough; Davis v. Whitehead [1894] 2 Ch. 133. The property had only been conveyed to him to enable him to raise mortgage finance.

75 Aveling Barford Ltd. v. Perion Ltd. [1989] B.C.L.C. 626.

76 At para. [52]. If this is the test, why are the company let cases not also "in substance an unlawful contracting out"? In those cases the letting is "in substance" to the occupier rather than the company. 
cases to reveal what it is that the parties really intend, as against what the face of the agreement suggests. In Bankway Arden L.J. took great care to explain why clause 8 (b)(iii) is not a provision for the payment of rent: it was not negotiated, it does not make clear that security of tenure was for less than two years, the landlord never tried to justify it as a market rent, and the rent was not raised to $£ 25,000$ at the earliest opportunity. The conclusion she reached is that the landlord never expected to receive this rent and intended it only as a means of recovering possession [para. 54], it was a device and "was not in substance a provision for the payment of rent". It is hard to explain why any of these factors affect the validity of the clause: they are all features that point to the artificiality of the clause and reveal the motive behind it, but this does not prevent it from being a rent clause which the landlord intended to implement. In Antoniades v. Villiers the substance and reality was that a lease had been entered into and not a licence because there was never any serious intention to rely on clause 16 . In Bankway the landlord intended very much to rely upon clause 8(b)(iii). The reality is that the lease included a lawful rent clause, the rent would be demanded even though it was probable that the higher rent would never be paid. ${ }^{77}$ Rent arrears is not an "additional way of ending the tenancy" but one of the grounds provided by the Housing Act 1988 for doing so. Devious the clause may be, but it is hard to see how it is an unlawful contracting out of the legislation given that the legislation permits the landlord and tenant to agree the initial rent and any provisions for reviewing it.

Pill L.J. preferred to base his decision on clause 8(b)(iii) being "inconsistent with the statutory purpose which it was the main object of the agreement to achieve." It is clear that the parties in Bankway intended for there to be an assured tenancy, and, although there may be some room for argument about whether it can really be said to be a "statutory purpose" or not, assured tenancies usually confer security of tenure as possession can only be recovered if specified grounds exist. According to Pill L.J. the clause allowing "for an increase of rent to $£ 25,000$ is inconsistent with and repugnant to the statutory purpose which, in the circumstances, is incorporated into the agreement ... and must be ignored" [para. 70]. Pill L.J. had difficulties with the concept of unlawful contracting out relied on by Arden L.J. because of the fact that it is not unlawful to contract out of the Housing Act

${ }^{77}$ Compare "... it is most unusual for a tenancy to be granted at a rent significantly in excess of the market rent ... particularly to a company with no significant property ... While that emphasises the artificiality of the transaction, these points do not render the agreements shams." Per Neuberger J. in National Wesminster Bank plc v. Jones [2001] 1 B.C.L.C. 98 at para. [61]. 
1988. The parties could, he pointed out, have entered into an assured shorthold tenancy which does not give security of tenure. ${ }^{78}$

The authority Pill L.J. relies on for the test being one of inconsistency with the statutory purpose is Glynn v. Margetson, in which Lord Halsbury said, and Pill L.J. quotes: "one must reject words, indeed whole provisions, if they are inconsistent with what one assumes to be the main purpose of the contract". ${ }^{79}$ The statutory purpose of the contract in Bankway is, according to Pill L.J., "long-term protection for the tenant", and clause 8(b)(iii) is inconsistent with this. There are, however, difficulties in using Glynn in this manner. Firstly, Glynn is a rule relating to the construction of contractual exclusion clauses. The "main purpose rule" is used to limit the application of wide exclusion clauses if, when given their literal meaning, they are inconsistent with the main object of the contract. In Glynn the main purpose of the contract was to carry oranges from Malaga to Liverpool. A clause in the charterparty enabled the ship to stay at any of a large number of ports before reaching Liverpool. The ship did not take a direct route, and delay caused by the deviation meant that the oranges arrived damaged. The House of Lords said that the general words used in the clause should be limited having in view the main object and intent of the contract, with the result that the liberty to deviate was limited to ports in the course of the agreed voyage. Bankway was not concerned with exclusion clauses at all. The second problem with using Glynn in Bankway is that in Glynn the "main purpose" is determined by the parties' shared commercial objective, whereas in Bankway Pill L.J. identifies the purpose from the statutory regime applicable to assured tenancies. No other cases have applied the main purpose rule to a statutory purpose. ${ }^{80}$ Further, although it is true that an assured tenancy usually gives long-term security, ${ }^{81}$ this was certainly not a shared contractual objective in Bankway. The assured tenancy route was a necessary one for the landlord to use to take advantage of the fiscal regime available under Business Expansion Schemes, but the grant of security of tenure was clearly not part of the purpose intended by the landlord.

78 At para. [65]. Had they "contracted out" of the Act by using an assured shorthold, the tenants would, however, have been "warned" of the limited security they would have by the prior issue of a notice.

79 [1893] A.C. $351,357$.

80 An Indian Supreme Court decision, Skandia Insurance Co. Ltd. v. Kokilaben Chandravan, A.I.R. 1987 S.C. 1184, does so and is referred to by Rix J. in Deepak Fertilisers v. ICI [1998] 2 Lloyds Rep. 139, but noting at para. [74] that "Skandia was itself a somewhat special case, and not one from which it is easy to draw wide conclusions."

${ }^{81}$ It is not always the case, however, as an assured tenancy can be brought to an end, for example, if the landlord wants to occupy the house himself, or if it is a winter let: see Housing Act 1988, Sch. 2. 
Neither the doctrine espoused by Pill L.J. or by Arden L.J. was a straightforward application of previous law. As witnessed by the vacillations of the Ramsay principle in tax law, the question of the legitimacy of avoidance techniques is a vexed one. On the whole, the judicial response has tried to avoid moral judgment: so long as an act is genuinely done and intended, then it is treated as permissible unless prohibited by express statutory wording or by necessary implication from the wording of the statute.

The Court of Appeal's response in Bankway steps beyond this approach: in doing so, it is hard to avoid the conclusion that they were reaching a moral judgment. If morality, or fairness is to be the guide, we need to identify just what it is about the factual situation in Bankway that causes disturbance. It cannot be simply because the tenants had no security of tenure: they could easily have been required to enter into an assured shorthold tenancy and could have found themselves dispossessed on only two months' notice. The disproportionality between the amount of the rent being demanded and the market value of the accommodation appears unfair, but there is nothing in the Housing Act 1988 that places a ceiling on rent levels. In part, it may be because of the element of "surprise" in that the tenants had never read the lease or had the rent provisions explained to them (even though they may well have agreed to this had they known of it because they were desperate to find accommodation) but this was not the basis of the Court of Appeal's decision and would, in any event, be addressed through general contract law rather than anything specific to the rent legislation. There is also the fact, as Arden L.J. points out, that the impact of the provision was to create a substantial personal judgment against them, which could even lead to their bankruptcy - but again this flows from the absence of statutory control of rent levels. In reality it is not any one factor in isolation that causes the unfairness, but all of these factors woven together. Nonetheless, from the tenants' perspective, the essence of the unfairness is surely the fact that the landlords have raised the rent to an unaffordable level against their expectations. The unfairness is not really to do with security of tenure. Although not available to the Court of Appeal in Bankway because of the date that the tenancy agreements were entered into, these concerns with fairness are better addressed through the consumer contracts legislation which can accommodate concerns over both procedural and substantive fairness.

The Court of Appeal in Bankway faced a difficult decision. Had it been possible to draw on the Unfair Terms in Consumer Contracts Regulations they could have isolated the factors causing 
concern and addressed the problem as one of consumer protection. This is what is really at issue in the case: there was an unequal bargaining relationship in which the tenants were surprised (or tricked?) by a substantively unfair rent clause that they not even seen, yet alone negotiated, and the entirely predictable inability to pay would lead to the loss of their home. Unable to address the issue as one of fairness, Arden and Pill L.JJ. were forced to look elsewhere for a solution. As shown in the earlier part of this article, however, courts have been reluctant to strike down avoidance motivated devices: they will do so only if the documentation does not represent the true (genuine) relationship between the parties or if there is an unlawful contracting out. Even though the doctrine of "sham" has been interpreted in an unduly restrictive manner by the courts in the past, it is nonetheless only to do with disabling a "shammer/pretender" from relying on the outward appearance of documented, but not genuinely intended, rights to the disadvantage of a party "innocent" of the sham. With the possible exception of Gisborne v. Burton, there is no support in previous case law for an approach which strikes down devices simply because they are artificial and designed to defeat statutory rights. Nor has the doctrine of "contracting out" been used in this manner. Although dicta of Lord Simon in Johnson v. Moreton might support a wide application, the other members of the House of Lords were careful to explain the decision as one stemming from the mandatory language used in section 24 of the Agricultural Holdings Act 1948 and from the public interest in securing a stable rural farming community. It has not previously been applied beyond the agricultural setting or to indirect forms of contracting out. In Bankway the device chosen was genuine, in the sense that the landlord did intend to increase the rent, and increasing the rent was not unlawful under the Housing Act. In finding the rent provision to be an impermissible device the Court of Appeal has pushed the law to a new stage. No longer will it be sufficient to ask if something is genuine, or allowed; instead the test will be whether "in substance" it is allowed. This will be a much more difficult question to answer. 